Cytogenet Genome Res 1996;75:I-IV

Contents, Vol. 75, 1996

Founded 1962 as 'Cytogenetics' by H.P. Klinger

Editor-in-Chief

H.P. Klinger

Department of Molecular Genetics

A bert Einstein College of Medicine

Bronx NY 10461-1602. US

Tel.: (7 18) 430-2451; Fax: (71 8) 430-2454

E-mail: hklinger(a),aecom.yu.edu

Managing Editor

J.A. Hartz

(address as for H.P. Klinger) E-mail: hartz@aecom.yu.edu

Editorial Administrator

B. Callaci, Bronx, NY

\title{
Co-Editor-in-Chief
}

Molecular cytogenetics and molecular pathology

L.A. Cannizzaro

Department of Pathology

Afbert Einstein College of Medicine

1300 Morris Park Ayenue

Tel.: (7 18) 430-2898; Fax: (718) 430-8633

E-mail: cannizza(a),aecom.yu.edu

\section{Assistant Editors}

E.S. Geffner, Huntington, NY PH. Geffner, Huntington, NY

Executive Editors

Gene mapping, cloning, molecular genetics

T.B. Shows

Repartment of Human Genetics

koswell Park Cancer Institute

Elmand Carlon streets

Tel.: (716) 845-3108; Fax: (716) 845-8449

E-mail: tbs(a,shows.med.buffalo.edu

Molecular cytogenetics, gene mapping,

somatic cell genetics, informatics

PL. Pearson

Pepartment of Human Genetics

Utrecht University 


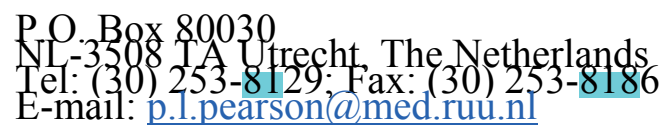

Associate Editors and Sections

Comparative cytogenetics

O.J. Miller

Molecular Biology and Genetics

3216 Scott Hall of Basic Medical Sciences

Wayne State Uniyersity School of Medicine

540 East Cantield Ayenue

Tel: (313) 579-5323; Fax: (313) 577-5218

E-mail: olmiller(a),cmb.biosci.wayne.edu

M. Schmid

Pepartment of Human Genetics

niversity of Wuifzburg

Biozentrum Am Hubland

Tel.: (931) \&88-4077; Gax: (931) 888-4069

E-mail:m.schmid@,biozentrum.uni-wuerzburg.de

Gene mapping and cloning T.W. Glover

Department of Human Genetics

4708 Med. Sc1. II. Box 0618

Unversity of Michigan

Ann Arbor M1 48 109-0618

Tel: (313) 763-5222; Fax; (313) 763-3784

E-mail: glover(a)umich.edu

Genetic regulation of cell malignancy

G.Klein

Microbiology and Tumor Biology Center (MTC)

arolinska institutet, Box 280

Tel.: (08) 728 64 00; Fax: (08) 330498

Molecular cytogenetics and gene mapping

J.R. Korenberg

Medical Genetics Birth Defects Center

Cedars-SinaiMedical Center

pavis

os Ángeles CA 90048 . USA

TeP.:(3T.0) 855-7627; Fax: (310) 652-8010

E-mail: jkorenberg@,mailgate.csmc.edu

Somatic cell genetics

D. Bootsma

Pepartment of Cell Biology and Genetics

Erasmus University

Rotterdam The Netherlands

Tel.: (010) 408 71 86; Fax: (010) 436-0225

U. Francke

Department of Genetics

Howard Hughes Medical Institute

Beckman Center for Molecular and

Genetic Medicine

stanford University Medical Center

Tel.: 415) 725-8089; Fax: (415) 725-8112

E-mail: mh.uta@,torsythe.stanford.edu

Editors

A. Baldini, Houston, TX

A. Bernheim, Villejuif

A. Bowcock, Dallas, TX

G. Camerino, Pavia 
R.S.K. Chaganti, New York, NY

A. Chakravarti, Cleveland, $\mathrm{OH}$

M.M. Cohen, Baltimore, MD

D.W. Cox, Toronto, Ontario

P. de Jong, Buffalo, NY

D.L. George, Philadelphia, PA

A. Hagemeijer, Rotterdam

I. Hansmann, Göttingen

B. Horsthemke, Essen

M.C. King, Berkeley, CA

M. Lalande, Boston, MA

P. Lichter, Heidelberg

L. Manuelidis, New Haven, CT

P.J. Mc Alpine, Winnipeg, Manitoba

D. Miller, Detroit, MI

Y. Nakamura, Tokyo

D. Nelson, Houston, TX

D. Pinkel, San Francisco, CA

H.-H. Ropers, Nijmegen

J.B. Searle, York

N. Shimizu, Tokyo

N.K. Spurr, South Mimms

B.J. Trask, Seattle, WA

J. Trent, Bethesda, MD

M. Van der Ploeg, Leiden

S.T. Warren, Atlanta, GA

J. Weissenbach, Evry

T.L. Yang-Feng, New Haven, CT

\section{KAIUIER}

Medical and Scientific Publishers Basel • Freiburg • Paris • London New York • New Delhi • Bangkok Singapore $\bullet$ Tokyo $\bullet$ Sydney

The authors and the publisher have exerted every effort to ensure that drug selection and dosage publication. However, in view of ongoing research, changes in government regulations, and the publication. However, in view ol ongolng research, changes in government regulations, and the check the package insert for each drug for any. change in indications and dosage and for added warnings and precautions. This is particularly important when the recommended agent is a new and/or infrequently employed drug.

gid/orinfrequently

No part of this publication may be translated into other languages, reproduced or utilized in any form or by any means, electronic or mechanical, including photocopying recording,

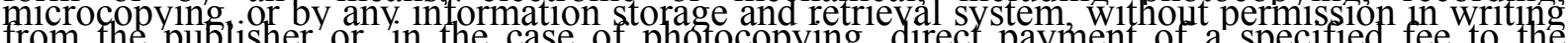
Copyright clearance Center (

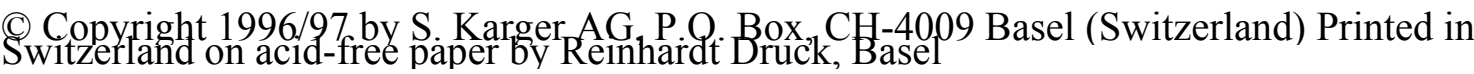

II

Contents Vol. 75, 1996

Cytogenetics and Cell Genetics

No. 1 
17 Chromosome imbalances in papillary renal cell carcinoma and first cytogenetic data of familial cases analyzed by comparative genomic

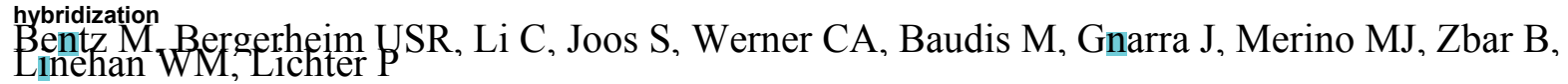

67 Alterations of yeast artificial chromosome transgenic sequences in stretched embryonic stem-cell chromatin visualized by fluorescence

in situ hybridization Rosenberg C, Voltz AK, Lawler AM, Lamb BT, Stetten G, Gearhart JD

45 A finding of the $X \times / X l_{1} W_{2}$ sex-chromosome system in Taterillus arenarius (Gerbillinae, Rodentia) and its phylogenetic implications

Volobouev V, Granjon L

49 Molecular characterization of the complex sex-chromosome heterochromatin in the rodent Microtus chrotorrhinus

Ivanov SV, Modi WS

57 Development of DNA liḅraries specific for Chinese hamster chromosomes 3,4,9,10, X, and Y by DOP-PCR

Xiao Y, Slijepcevic P, Arkesteijn G, Darroudi F, Natarajan ÁT

63 Generation of mouse chromosome painting probes by DOP-PCR amplification of microdissẹcted meiotic chromosomes

Xiao Y, Darroudi F, Kuipers AGJ, de Jong JH, de Boer P, Natarajan AT

No. 2-3

Gene Mapping, Cloning, and Sequencing

2 Molecular cloning of the papillary renal cell carcinoma-associated translocation (X;1)(p11;q21) breakpoint Weterman MAJ, Wílbrink M, Janssen I, Janssen HAP, van den Berg E, Fisher SE, Craig I,

14 Genetic mapping of GLCLC, the human gene encoding the catalytic subunit of y-glutamylcysteine synthetase, to chromosome band $6 \mathrm{p} 12$ and characterization of a polymorphic trinucleotide repeat within its 5' untranslated region Walsh AC, Li W, Rosen DR, Lawrence DA

36 Assignment of the human slow twitch skeletal muscle/cardiac troponin C gene (TNNC1) to human chromosome 3p21.3-3p14.3 using somatic cell hybrids

Sonatic cell hybrids

Animal Cytogenetics and Comparative Mapping

7 Mapping of the genetically independent chicken major histocompatibility complexes $B @$ and $R F P$-Y@ to the same microchromosome by two-color fluorescent in situ hybridization

Fillon V, Zoorob R, Yerle M, Auffray C, Vignal A

10 High-resolution FISH mapping of ß-defensin genes to river buffalo and sheep chromosomes suggests a chromosome discrepancy in

Iannuzzi L, Gallagher DS, Di Meo GP, Diamond G, Bevins CL, Womack JE

22 Comparative mapping of $\mathrm{Na}^{*}$-phosphate cotransporter genes, NPT1 and NPT2, in human and rabbit

Kos CH, Tihy F, Murer H, Lemieux N, Tenenhouse HS

$\mathbf{2 5}$ Cloning of the bovine activin receptor type Il gene (ACVR2) and mapping to chromosome 2 (BTA2)

Flavin N, Heriz A, Monteagudo LV, Ennis S, Martin F, Barendse W, Arruga MV, Rogers M

30 Assignment of the ATBF1 transcription factor gene (Atbfll to mouse chromosome band 8E1 by in situ hybridization

Yamada K, Ma D, Miura Y, Ido A, Tamaoki T, Yoshida MC

32 Chromosome homology between the domestic pig and the babirusa (family Suidae) elucidated with the use of porcine painting probes Bosma AA, de Haan NA, Mellink CHM, Yerle M, Zijlstra C

38 Identification and chromosome mapping of the mouse

homologue of the human gene (DDX6) that encodes a putative RNA helicase of the DEAD box protein family

Akao Y, Matsuda Y

Special Notice to Contributors opposite 71

All manuscripts should now be e-mailed or mailed directly to the main editorial office in New York

Chromosome Workshops

71 Report of the Third International Workshop on Human Chromosome 8 Mapping 1996

85 Report of the Third International Workshop on Human Chromosome 13 Mapping 1995

III Report of the Fourth International Workshop on Human Chromosome 18 Mapping 1996

Original Articles

151 In vivo cytogenetic damage revealed by FISH analysis of micronuclei in uncultured human T lymphocytes Surrallés J, Falck G, Norppa H 
155 The Ag-NOR proteins present a crescent-shaped distribution at the secondary constrictions of metaphase PtK chromosomes

Suja JA, Hernandez-Verdun D

167 Application of micro-FISH to delineate deletions Engelen JJM, Albrechts JCM, Loots WJG, Hollanders-Crombach BHTM, Hamers AJH,

172 Complementary replication R- and G-band patterns induced by cell blocking at the R-band/G-band transition, a possible regulatory checkpoint within the $S$ phase of the cell cycle

Fetni R, Drouin R, Richer C-L, Lemieux N

Gene Mapping, Cloning, and Sequencing

132 Human CLAPS2 encoding AP17, a small chain of the clathrin-associated protein complex: cDNA cloning and chromosomal assignment to 19q13.2-q13.3

Winterpacht A, Endele S, Enklaar T, Fuhry M, Zabel B

180 Mapping of 29 YAC clones and identification of 3 YACs

spanning the translocation $\mathrm{t}(3 ; 8)(\mathrm{p} 14.2 ; \mathrm{q} 24.1)$ breakpoint at $8 \mathrm{q} 24.1$ in hereditary renal cell carcinoma

Shi G, Cannizzaro LA

\section{KARXiER}

E-Mail karger@,karger.ch Fax+41 613061234 http://www.karger.ch

(C)1996S. KargerAG, Basel

The list of contents is available at: http:/www.karger.ch/journals/ccg/ccgcont.htm

III

186 Genomic localization of the human gene encoding DM, a negative modulator of transcription of class II and class III genes

Purrello M, Di Pietro C, Rapisarda A, Viola A, Corsaro C, Motta S, Grzeschik K-H, Sichel G

190 Isolation of 45 exon-like fragments from 8 p22-p21.3, a region that is commonly deleted in hepatocellular, colorectal, and non-small cell lung carcinomas

Chinen K, Isomura M, Izawa K, Fujiwara Y, Ohata H, Iwamasa T, Nakamura Y

197 Molecular analysis of the genomic structure of the human $Y$ chromosome in the euchromatic part of its long arm (YqlI)

Kirsch S, Keil R, Edelmann A, Henegariu O, Hirschmann P, LePaslier D, Vogt PH

Animal Cytogenetics and Comparative Mapping

136 Chromosome mapping of rat histone genes Hlfv, Hid, Hit, Th2a and Th2b

Walter L, Klinga-Levan K, Helou K, Albig W, Drabent B, Doenecke D, Günther E, Levan G

140 Characterization and Mapping of the Xiphophorus maculatus (Teleostei: Poeciliidae) RPS15 gene

WA, Nairn RS

145 Sex chromosome linkage of 5S rDNA in rainbow trout (Oncorhynchus mykiss)

Moran P, Martinez JL, Garcia-Vazquez E, Pendas AM

159 Spontaneous and aphidicolin-sensitive fragile site 3 cen co-localizes with the (TTAGGG) $n$ telomeric sequence in Chinese hamster cells

Musio A, Rainaldi G, Sbrana I

164 Allelic fusion of DNA topoisomerase Il $\alpha$ and retinoic acid receptor $\alpha$ genes in Adriamycin-resistant p388 murine leukemia revealed by

Squire JA, McPherson JP, Beatty BG, Goldenberg GJ

206 Addendum to Abstracts of the 12th European Colloquium on Cytogenetics of Domestic Animals

No. 4

Special Notice to Contributors opposite 207

All manuscripts should now be e-mailed or mailed directly to the main editorial office in New York

Original Articles

216 Complex chromosomal mechanisms lead to APRT loss of heterozygosity in heteroploid cells

Shao C, Gupta PK, Sun Y, Sahota A, Tischfield JA

243 FISH detection of chromosome polymorphism and deletions in the spinal muscular atrophy (SMA) region of 5q13

Raican-Separovic E, Mahadevan MS, Lefebvre C, Besner-Johnston A, Ikeda J-E, Korneluk RG, Mackenzie A

248 A new method for detecting pericentric inversions using COD-FISH

Bailey SM, Meyne J, Cornforth MN, McConnell TS, Goodwin EH 
258 Horseradish peroxidase-labeled oligonucleotides and fluorescent tyramides for rapid detection of chromosome-specific repeat

van Gijlswijk RPM, Wiegant J, Vervenne R, Lasan R, Tanke HJ, Raap AK

263 Simultaneous enumeration of chromosomes 13,18,21, $X$, and $Y$ in interphase cells for preimplantation genetic diagnosis of aneuploidy Munné S, Weier H-UG

Gene Mapping, Cloning, and Sequencing

210 Isolation of cosmids corresponding to the chromosome breakpoints of a de novo autosomal translocation, (6;19)(p21;q13.1), in a patient with multicystic renal dysplasia

Groenen WJMA, Garcia E, Thoelen R, Aly M, Schoenmakers EFPM, Devriendt K, Fryns JP, Van

222 Assignment of the gene for a ubiquitin-conjugating enzyme (UBE2I) to human chromosome band 16p13.3 by in situ hybridization Tachibana M, Iwata N, Watanabe A, Nobukuni Y, Ploplis B, Kajigaya S

224 A pseudogene for the human ribosomal protein L5 (RPL5P1) maps within an intron of the SNRPN transcription unit on human chromosome 15

Buiting K, Kaya-Westerloh S, Horsthemke B

227 Assignment of the human proprotein convertase gene PCSK5 to chromosome 9q21,3

van de Loo J-WHP, Creemers JWM, Kas K, Roebroek AJM, Van de Ven WJM

230 Complete coding sequence, exon/intrọn arrangement and chromosome location of ZNF45, a KRAB-domain-containing gene Constantinqu Deltas C, Bashiardes E, Patsalis PC, Hadiimarcou M, Kroisel PM, Ioannou PA, Roses AD, Lee JE

254 A novel multicolor hybridization scheme applied to

localization of a transcribed sequence (D10S170/H4) and deletion mapping in the thyroid cancer cell line TPC-1
Jossart GH, O'Brien B, Cheng JF, Tong Q, Jhiang SM, Duh Q, Clark OH, Weier H-UG

Animal Cytogenetics and Comparative Mapping

207 Conservation of human chromosome 18 in baboons (Papio hamadryas): a linkage map of eight human microsatellites

Perelygin AA, Kammerer CM, Stowell NC, Rogers J 234 Characterization of an atypical NOR site polymorphism in brown trout (Salmo trutta)

with $\mathrm{Ag}$ - and $\mathrm{CMA}_{3}$-staining, and fluorescent in situ hybridization

Castro J, Viñas A, Sanchez L, Martinez P

240 Six antimicrobial peptide genes of the cathelicidin family map to bovine chromosome $22 q 24$ by fluorescence in situ hybridization

Castiglioni B, Scocchi M, Zanetti M, Ferretti L

271 Author Index Vol. 75, 1996273 Subject Index Vol. 75,1996

IV

Cytogenet Cell Genet Vol. 75, 1996 